\title{
AN AFTERTHOUGHT
}

\author{
WHY WE SHOULD TELL STORIES OF THE BRITISH WORLD
}

\author{
PAUL A. PICKERING
}

The Australian National University

According to the Royal Mail, Britons post approximately 10 million Christmas cards to Australia every year. ${ }^{1}$ This extraordinary volume of seasonal felicitations is a reminder that at its core the British world is a corporeal system. It is easy to forget the magnitude of the British Diaspora over the past 400 years. Between 1600 and 1800 more than one million people emigrated from England, Scotland and Wales, mainly across the Atlantic to North America. ${ }^{2}$ In the 60 years between 1853 and 1913 just under 13 million British citizens left the United Kingdom as migrants headed for extra-European ports; a further 7.3 million migrated in the period 1951 to $1998 .{ }^{3}$ Britons at home and abroad have long understood that the British world was a thing of flesh and blood. 'Thousands of us, home-staying people in England', wrote Richard Acton in 1881, 'have been called by family duties or friendships, perhaps more than once in our lives, to come down to Gravesend, to bid farewell to those whom we love.' 'There are so many people', he continued, 'who have a son or a brother in our colonies. ${ }^{4}$ The ties of kinship have per- sisted despite the fact that Britain has long since turned its gaze to Europe and, in turn, the 'better Britains' of the southern seas look increasingly to Asia and the Pacific. At the beginning of the twenty-first century, for example, nearly 1.2 million Australians reported to the census collectors that they had been born in the United Kingdom; many more could point to one of their parents or grandparents who had been born in 'old Blighty'. 5

Over the past two decades the related ideas of 'Britishness' and 'the British world' have undoubtedly breathed new life into the study of Anglophone societies. Thankfully now fewer historians refer to Britain when they mean England, or worse, write of England when they mean Britain. ${ }^{6}$ Moreover, those who study 'other' Britons - people that were on or outside the political and cultural margins due to their gender, race, income or religion, that lived far from the imperial capital in the provinces or in the colonies of settlement - have, in particular, benefited from (and contributed to) what is often called the 'new British history'. There is a greater understanding of the way in 
which ideas and individuals moved around the British world, not simply from centre to periphery.

The study of 'other' Britons raises definitional issues. According to the OED the earliest use of the word 'Britishness' equated it with Brutishness. 'Primitive Britishness', one observer noted in 1682, 'was never acquainted with the habiliment of a Shirt. ${ }^{7}$ Since then there have been many attempts to define it: from Walter Murdoch's suggestion that above all other associations (race, language, tradition, custom and ideas) the link between those who lived in the empire on which the sun never set was that they were 'subjects of the same sovereign', to T.S. Eliot's glib index of British culture: 'Derby Day, Henley Regatta, Cowes, the twelfth of August, a cup final, the dog races, the pin table, the dart board, Wensleydale cheese, boiled cabbage cut into sections, beetroot in vinegar, nineteenth-century Gothic churches and the music of Elgar'; from Linda Colley's emphasis on Protestantism and enmity to France, to Gordon Brown's assertion that the 'golden thread' that runs through British history is 'a passion for liberty anchored in a sense of duty and an intrinsic commitment to tolerance and fair play' $^{\prime}{ }^{8}$

By examining its many variations the essays in this volume - a selection of those presented at the symposium in 2004 - all contribute to the expanding definition of Britishness as a political, social, cultural and racial category. The presentations were all concerned with people whose claim to Britishness was marginal and contested. What did it mean to be 'British' in Cape Town, Aberdeen, Calgary or Dunedin? What did it mean to be 'British' if you were poor, an Irish Catholic, a radical reformer, a Jew or a woman? The ensuing discussion which is, in turn, reflected in the essays in this volume, made it clear that further study will question, challenge and perhaps even destabilise the notion of Britishness. Indeed there is a danger that the concept will fracture under the weight of additional research. Unfortunately, this would encourage many to retreat behind the more familiar and secure palisades of national, regional and local history. It is, nevertheless, worth the risk. Moreover it was apparent from the symposium, at least to this observer, that a productive way to explore the myriad varieties of Britishness without undermining the 'new British history' is to use biography as a lens; to tell stories of the British world. By way of illustration and conclusion here are three.

At the York Assizes of 1830 a 26-yearold linen weaver from Barnsley named William Ashton was tried for riot and sedition and sentenced to 14 years' transportation. He spent five years of his sentence in Van Diemen's Land where he was appointed to the relatively privileged position of 'Convict Constable' but was later suspended, fined and briefly imprisoned for a succession of misdemeanours. ${ }^{9}$ The bonds of kinship and community were not easily broken. After seven years, a petition from his friends and neighbours in Yorkshire secured his release and a subscription paid his passage home. Following his return, Ashton was unable to pursue his former trade - radicals and trade unionists often could not find employment and he began a career as a political lecturer-cum-activist. His favourite subject was the brutality of convict life - 'I have seen ... the blood laying in pools between the stones, and the flesh flying from the 
end of the lashes', he reported - the salacious details of which added to his celebrity. ${ }^{10}$ Ashton's newfound avocation ensured that he would play a prominent part in the Chartist campaign for democratic reform of the British political system that was rapidly gathering pace during the winter of 1838-9. His comments in support of the use of violence to promote the Chartist cause soon brought him to the notice of the authorities and fearing incarceration he fled to France. For reasons that are unclear, Ashton returned to England after a short time on the continent and was arrested. At his trial in March 1840 he was sentenced to two year's imprisonment for sedition at Wakefield Prison. By this stage he was married with one child. ${ }^{11}$

Upon his release in March 1842 Ashton was defiant: 'my long confinement has not in any measure altered my former principles, or made me less anxious for, or willing to assist in, destroying the accursed system under which we live in wretchedness and degradation.' ${ }^{12}$ Soon, however, he became embroiled in a bitter public quarrel with other Chartist leaders and by the end of the year he and his family had decided to emigrate to America, settling in New York. They regretted it almost immediately. 'The people of America, so far as I have had an opportunity of judging', he wrote, 'are an ignorant, selfish and overbearing class of beings.' ${ }^{13}$ After 10 short months in the great republic the Ashtons again crossed the Atlantic to return to Barnsley where William managed to recommence his trade as a weaver. He remained politically active during the 1840s but in the early 1850s migrated with his son and daughter to Australia, settling in McCullum's Creek, half way between Ballarat and Maryborough on the Victorian goldfields, where they ran a store. Still the ties of kinship and community could not be broken. From his new home Ashton intermittently sent letters back to Yorkshire to be published in the local liberal newspaper, the Barnsley Chronicle. He wrote firstly to encourage his former townsfolk to emigrate, not to Victoria, where he argued that the squatter and the capitalist had a vice-like grip on access to the land, but to Queensland, New Zealand or (oddly, given his own experience) America. He also wrote to educate and to attempt to influence debate in Britain. One of his letters outlined the success of the ballot; another the virtues of protection. ${ }^{14}$ He met with very limited success. His panegyric on protection, for example, met with polite indifference. 'Controversy on protection has here so long been held to be dead and buried,' commented the editor, 'that its return to existence in a newspaper column is felt like the ghostly visit of a deceased friend to a family circle who had long forgotten him. ${ }^{\prime 15}$ The point is, however, not the reception but the attempt. For Ashton, McMullan's Creek and Barnsley were not separated by a tyranny of distance.

In February 1855 Henry Samuel Chapman was elected to the Victorian Legislative Council. At the time he had only been in the colony for a few months. Prior to that he had served a turbulent term as Colonial Secretary of Van Diemen's Land, a position from which he was ultimately dismissed following a dispute with Governor Denison over the latter's support for convict transportation. Turning down an offer of the governorship of the West Indies, Chapman chose instead to establish a law practice in Melbourne. Before his clash with Denison, Chapman had spent 
nearly a decade as a judge in Wellington on the north island of New Zealand where he had helped to establish the colony's Supreme Court. Although he had been born in London in 1803 it was the formative years that he spent in Quebec, where he worked as a clerk and agent representing English manufacturers during the 1820s, that shaped his future career. Whilst in Canada he began to dabble in economic theory and the fashionable ideas of the British philosophical radicals, as well as reading law, eventually being admitted to the Canadian Bar. During a visit to England in 1833 Chapman had his first taste of electoral politics involving himself in the campaign of a leading radical of the day, J.A. Roebuck. Back in Canada he commenced a radical newspaper, the Montreal Daily Advertiser, which was committed to representative and responsible government, allied causes that would resonate around the British world over the next twenty years. Chapman returned to England in 1835 as an agent of the Legislative Assembly of Lower Canada, seeking to cultivate support for their demands in the House of Commons.

Over the next few years Chapman became a familiar face at meetings of London's philosophical radcials. In addition to working on the Canadian cause with Roebuck - which culminated in the failed rebellion of 1837 - he also assisted John Stuart Mill to produce the London Review and John Bowring to edit the works of the pre-eminent English philosopher and leading philosophical radical, Jeremy Bentham. By the end of the decade Chapman had established himself as a political agent and publicist in London. In 1840 he became involved in the campaign against the Corn Laws, a protective tariff that butressed the power of the landowning aristocracy, becoming a founding member of the Metropolitan Anti-Corn Law Association and one its most successful publicists in the capital. At this time he also accepted government service as secretary to a parliamentary enquiry and he published extensively on New Zealand and systematic colonization. It was this latter interest that led to his appoinment to the New Zealand bench in $1843 .{ }^{16}$ As a member of the Victorian parliament in 1856 Chapman drafted the legislation that incorporated the secret ballot into the Electoral Act of the self-governing colony. Many years previously Chapman had penned, with Roebuck, a pamphlet on the virtues of the ballot which had been a staple of the radical program for a generation. It is ironic that Chapman's bill gave rise to what has become known amongst psephologists and political scientists as the 'Victorian (and later Australian) ballot' when its author, recently arrived in the colony, was truly a citizen of the British world.

In different ways both Ashton and Chapman were outsiders, committed to fundamental reform, who seized the opportunities presented by the wider British world as a platform for personal advancement. For all that the British aristocracy looked down their collective noses at their colonial cousins, the Imperial elite too was often integrated across the empire. Take Peter Alexander Rupert Carington, Sixth Lord Carrington, as an example. Carington is the archetypal British aristocrat: from Eton to Sandhurst to the House of Lords and high office (including the post of British High Commissioner to Australia and a place in every Conservative government from 1951 to 1979). Within the relatively recent past the story is much more 
interesting and diverse. In the middle of the eighteenth century Thomas Smith, a humble draper of 'good Yeoman stock' in Nottingham, extended his business from providing credit into banking. Thomas' business grew in the hands of his son who moved it to London and acquired a famous customer, William Pitt. Service to the Prime Minister led to ennoblement; first an Irish barony (the King demurred at easy promotion for those 'in trade') that was later converted to an English peerage. In 1839 the Smiths adopted the name Carington to match their title (although confusingly spelt with one ' $r$ '). The editor of The Complete Peerage was in no doubt that they had done so in order to associate themselves with an ancient noble family of Smiths who had held the peerage of Carrington in the 1640s. ${ }^{17}$ By the middle of the nineteenth century, however, the family was facing financial difficulty and Peter's grandfather, Rupert, went to New South Wales in the 'hope of relief from creditors' (his elder brother was already in residence as Governor of New South Wales). ${ }^{18}$ In Sydney Rupert Carington found financial salvation by marrying the daughter of John Horsfall, one of the leading sheep farmers in the colony. Rupert went on to be a Major in the New South Wales Mounted Rifles in 1901 and during the South African war commanded a regiment of the 'Imperial Bushman' before returning to England where he inherited the peerage from his elder brother in $1915 .^{19}$

The smell of sheep manure has long since dissipated but the Carington tale is still a story of the British world. These examples are a reminder that lives are complex, varied and surprising. There are many other stories of imperial, transnation- al and international lives to be told and retold. Although the days when an Australian Prime Minister, Robert Menzies, could insist that the 'boundaries of Great Britain are not on the Kentish coast but at Cape York [in Australia] and Invercargill [in New Zealand $]^{20}$ have passed, the legacy of the British world is instantiated 10 million times every Christmas. The same is true of the British world writ large.

\section{ENDNOTES}

${ }^{1}$ I am grateful to Carl Bridge, Director of the Menzies Centre for Australian Studies, for this information. The estimate dates from the 1980s. Australia Post is unable to provide a comparable statistic.

2 Horn, J., 1998, 'British Diaspora: Emigration from Britain, 1680-1815', in Marshall, P.J., ed., The Oxford History of the British Empire: Volume II: The Eighteenth Century, Oxford, pp. 28-52.

3 Hatton, T., 2004, 'Emigration from the UK, 18701913 and 1950-1998', European Review of Economic History, vol. 8, no. 2, p. 150.

4 Acton, R., n.d. [1881], Our Colonial Empire, London, p. 21.

5 Australian Bureau of Statistics, 1301.0 County of Birth 2004.

${ }^{6}$ See Davies, N., 1999, The Isles: A History, Oxford; Pickering, P.A., 1996, Review of E. Hopkins, Working Class Self Help in Nineteenth Century England', Albion, Winter, pp. 711-12.

7 The etymology of the term was noted by Ian Donaldson at the 'Britishness and Otherness' symposium held at the Humanities Research Centre, The Australian National University, July 2004.

8 Murdoch, W., 1912, The Australian Citizen: An elementary account of civic rights and duties, Melbourne, pp. 12-13; Eliot, T.S. 1954, Notes towards the definition of culture, London; Colley, L., 1992, Britons: forging the nation 1707-1837, New Haven; Brown, G. 'The golden thread that runs through our history', Guardian 8 July 2004.

${ }^{9}$ See Knott, J., 1982, 'A Chartist's view of Australia, 1838', The Push From the Bush: A Bulletin of Social History, 13, pp. 8-9; Saville, J. 1974, ' Ashton, William', Dictionary of Labour Biography, London, 3, pp. 5-8; Boston R., 1971, British Chartists in America, Manchester, p. 88. 
10 Ashton, W., 1838, A lecture on the evils of emigration and transportation, Sheffield, p. 15.

11 MSS. HO 20/10, Report from the Inspector of Prisons, 1840.

12 Cited in Barnsley Chronicle, 1 September 1877.

13 British Statesman, 10 December 1842.

14 See inter alia Barnsley Chronicle, 29 October 1864; 29 July 1865.

15 Barnsley Chronicle, 29 July 1865.

16 Entry by Neale, R.S., 1969, Australian Dictionary of Biography, Melbourne, 3, pp. 380-2; The Black and White List; Or, the Victorian Elector's Guide (East Melbourne, 1856), p. 2; Spiller, P., 1992, The Chapman Legal Family, Wellington; British Library, MSS. Place Collection, Set 56, vol. 2, fol. 5, vol 13, fol. 221f; vol. 16, fol. 138; vol. 16, fol. 257.

17 Reflect On Things Past: The Memoirs of Lord Carrington, London, 1988, p. 8.

18 Ibid. pp. 1-11.

19 See entry by Walsh, G.P., 1979, Australian Dictionary of Biography, Melbourne, 7, pp. 560-1.

20 Cited in Ward, S., 2001, Australia and the British Embrace, Melbourne, p. 20. 